\section{Jurnal Mitra Pendidikan (JMP Online)}

URL : http://e-jurnalmitrapendidikan.com
JMP Online

Vol. 4, No. 10, 645-659.

(C) 2020 Kresna BIP. e-ISSN 2550-0481 p-ISSN 2614-7254

\title{
UPAYA MENINGKATKAN LAYANAN BIMBINGAN KONSELING TENTANG ETIKA PERGAULAN MELALUI TEKNIK SOSIODRAMA PADA SISWA KELAS XII SMK LEMBANG
}

\author{
Khamdiyah \\ SMK Lembang Kabupaten Rote Ndao
}

INFORMASI ARTIKEL

Dikirim : 16 Oktober 2020

Revisi pertama : 21 Oktober 2020

Diterima : 27 Oktober 2020

Tersedia online : 03 November 2020

Kata Kunci: Konseling, Etika, Sosiodrama

Email: khamdiyah04@gmail.com
ABSTRAK

Penelitian ini menggunakan teknik sosiodrama pada layanan bimbingan konseling tentang etika pergaulan.

Tujuan dari penelitian ini adalah dengan teknik sosiodrama pada layanan bimbingan konseling peneliti ingin meningkatkan layanan bimbingan konseling etika pergaulan siswa kelas XII SMK Lembang.

Hasil penelitian menunjukan bahwa aktivitas siswa pada siklus 1 mendapat predikat $C$ dengan nilai 17 dan siklus II mendapat predikat B dengan nilai 24, ketuntasan nilai pada siklus I mencapai $50 \%$ dengan jumlah siswa yang tuntas 12 orang dari 24 siswa. Pada siklus II semua siswa kelas XII yang berjumlah 24 orang dinyatakan tuntas dan mencapai $100 \%$. Peningkatan ini naik mencapai 50\%. Berdasarkan hasil penelitian yang dilakukan maka disimpulkan bahwa dengan menggunakan teknik sosiodrama pada layanan bimbingan konseling etika pergaulan di kelas XII SMK Lembang dinyatakan tuntas dan tidak dilanjutkan pada penelitian ke siklus berikutnya. 


\section{PENDAHULUAN \\ Latar Belakang}

Manusia adalah makhluk sosial yang selalu berhubungan dan saling membutuhkan satu sama lain, setiap orang memiliki kekurangan dan kelebihan serta memerlukan bantuan orang lain. Kita dapat hidup karena saling tolong menolong. Dalam pergaulan di masyarakat, terdapat aturan-aturan yang dapat memisahkan antara hak dan kewajiban masing-masing orang (anggota masyarakat). Demikian juga di lingkungan sekolah, seorang siswa harus berpedoman pada aturan atau norma dalam berinteraksi dengan guru, teman dan semua warga sekolah. Masalah manusia pada umumnya di mana pun manusia berada dalam komunitasnya, pasti etika dan etiket ikut berperan sebagai pedoman tingkah laku baik-buruk dalam pergaulan sesama mereka. Remaja yang merupakan bagian dari manusia pada umumnya, juga memerlukan pedoman tingkah laku agar pergaulan sesama remaja dapat berjalan dengan baik sesuai dengan norma masyarakatnya atau sesuai dengan norma agama yang dianutnya, sehingga mereka terhindar dari pergaulan yang menyimpang yang tidak sesuai dengan norma masyarakat dan norma agama. Setiap pergaulan dengan guru, teman maupun semua warga sekolah, dibutuhkan suatu etika sebagai alat menilai baik-buruk suatu tindakan. Dalam dunia pendidikan pun demikian, karena etika merupakan hal yang paling mendasar yang menjadi pegangan manusia dalam bersosialisasi. Etika juga merupakan aturan konvensional mengenai tingkah laku individual dalam masyarakat beradab dan juga tata cara formal atau tata krama lahiriah untuk mengatur relasi antar pribadi, sesuai status sosial masing-masing individu. Etika didasarkan nilai kesopanan, saling menghargai, kejujuran, keterbukaan, dan kebaikan. Perilaku siswa yang tidak sesuai dengan etika, memerlukan perhatian dan penanganan yang khusus dari sekolah dan orang tua. Di kelas siswa memerlukan penanganan khusus dari guru bimbingan konseling. Salah satu teknik bimbingan dan konseling yang dapat dilakukan guru BK untuk membantu siswa memahami etika pergaulan adalah dengan teknik sosiodrama. Jadi, etika pergaulan adalah aturan sopan santun dalam pergaulan, yaitu memberikan dan menunjukkan cara yang tepat untuk bertindak dan berbuat. Etika menyangkut tata cara suatu perbuatan yang harus dilakukan. Etika berlaku dalam pergaulan sosial ketika ada orang lain yang melihat perbuatan atau tindakan yang dilakukan.

Berdasarkan observasi di kelas XII, ada beberapa siswa yang melanggar tata tertib sekolah, seperti ketika ditanya guru mereka menjawab dengan tidak sopan. Siswa menggunakan bahasa kasar terhadap orang lain, suka memotong pembicaraan orang lain, siswa memakai seragam sekolah tidak sesuai dengan peraturan yang ada di sekolah dan kurang menghargai guru, pada saat guru sedang mengajar di depan kelas, di belakang kelas beberapa siswa berjalan-jalan, siswa bercerita dengan teman dan siswa tidak menjawab pertanyaan guru lebih memilih diam. Masalah ini sering dialami guru mata pelajaran BK pada saat kegiatan pembelajaran di kelas dan harus dicari jalan keluar untuk mengatasinya.

Dari penjelasan tersebut di atas peneliti dapat simpulkan bahwa metode sosiodrama jika diterapkan dengan serius akan didapatkan sebuah hasil yang maksimal terhadap siswa. Menurut Sanjaya teknik Sosiodrama merupakan teknik yang tepat digunakan untuk membantu meningkatkan kemampuan etika pergaulan 
siswa dalam interaksi dengan teman sebaya dan orang lain. Melalui teknik sosiodrama, sebagai pemecahan masalah yang dialami siswa dapat meningkatkan regulasi emosi siswa karena siswa akan diarahkan untuk mengembangkan sikap kritis terhadap tingkah laku individu. Metode ini sangat cocok sebagai metode untuk menumbuhkan sikap etika pergaulan pada siswa. Hal ini dikarenakan pada saat melakukan simulasi siswa akan merasa seolah-olah menjadi pelaku sebuah kejadian sejarah sehingga esensi dari peristiwa akan mudah diserap oleh siswa. Diharapkan penerapan metode ini akan menghasilkan sebuah perubahan tingkah laku seperti yang diharapkan. Pemilihan penggunaan teknik sosiodrama didasarkan pada alasan karena permasalahan yang muncul berkaitan dengan permasalahan sosial yaitu etika pergaulan siswa yang sering sekali ke arah negatif di lingkungan sekitar utamanya dan lingkungan sekolah, sehingga sosiodrama dipandang tepat untuk meningkatkan sopan santun. Melalui teknik sosiodrama, siswa akan belajar bagaimana etika pergaulan yang baik terhadap orang lain dalam bentuk kegiatan memainkan sebuah peran. Teknik tersebut dapat memberitahu siswa bagaimana sebenarnya etika pergaulan yang baik dalam lingkungan sekolah, keluarga maupun di masyarakat.

Berdasarkan uraian di atas, maka peneliti tertarik untuk mengadakan penelitian tentang Upaya Meningkatkan Layanan Bimbingan Konseling Tentang Etika Pergaulan Melalui Teknik Sosiodrama Pada Siswa Kelas XII SMK Lembang.

\section{Rumusan Masalah}

Berdasarkan latar belakang diatas, maka rumusan masalah dalam penelitian ini adalah bagaimana upaya meningkatkan layanan bimbingan konseling tentang etika pergaulan melalui teknik sosiodrama pada siswa kelas XII SMK Lembang?

\section{Tujuan Penelitian}

Berdasarkan rumusan penelitian di atas, maka tujuan penelitian ini adalah dengan teknik sosiodrama pada layanan bimbingan konseling peneliti ingin meningkatkan layanan bimbingan konseling tentang etika pergaulan siswa kelas XII SMK Lembang.

\section{KAJIAN PUSTAKA \\ Pelaksanaan Bimbingan dan Konseling}

Abdul Jalaludin (2010) Pelaksanaan Bimbingan dan konseling Bimbingan dan Konseling juga merupakan bagian dari sistem pendidikan yang mampu membantu siswa dalam mengembangkan potensinya. Berkaitan dengan hal tersebut sesuai dengan UU No.22 tahun 2013 tentang konsep dasar dan fungsi pendidikan menjelaskan bahwa bimbingan dan konseling mempunyai peluang yang sangat terbuka dalam keseluruhan sistem pendidikan nasional. ABKIN (2010) Bimbingan dan konseling juga berperan penting dalam memajukan pendidikan yang lebih baik, karena dalam Bimbingan dan Konseling memiliki empat bidang layanan yang dapat membantu siswa untuk dapat mengoptimalkan potensi yang ada dalam diri siswa tersebut. 
Afifudin, (2012). Dalam pelaksanaan layanan bimbingan dan konseling di sekolah perlu dioptimalkan dengan baik, terkait dengan empat bidang dalam bimbingan dan konseling yaitu, bidang pribadi, sosial, belajar dan karir. Menurut Sukardi dalam suryani terdapat tujuh jenis layanan yang terdiri dari layanan orientasi, layanan informasi, layanan penempatan dan penyaluran, layanan pembelajaran, layanan konseling individu, layanan bimbingan kelompok, layanan konseling kelompok. Sejalan dengan hal tersebut Sukardi juga mengemukakan bahwa terdapat lima rencana kegiatan pendukung bimbingan dan konseling yang terdiri dari aplikasi instrumen, himpunan data, konfrensi kasus, kunjungan rumah, alih tangan kasus.

Menurut Ahman (2013) terdapat empat bidang layanan bimbingan dan konseling yaitu: bimbingan dan konseling akademik (belajar), bimbingan dan konseling pribadi, bimbingan dan konseling sosial, bimbingan dan konseling karir. Bimbingan dan konseling berperan penting dalam mensukseskan dunia pendidikan yang lebih baik, untuk menciptakan semua hal itu tentu dalam pelaksanaan layanan tersebut harus memiliki sistem manajemen yang baik. Menurut Anas Salahudin. 2012 mengemukakan bahwa pelaksanaan bimbingan dan konseling bertujuan untuk membantu peserta didik agar dapat mencapai tujuan-tujuan perkembangan meliputi aspek pribadi, sosial, belajar dan karier. Bimbingan dan konseling di sekolah merupakan usaha bantuan yang diberikan kepada individu didalam memperoleh penyesuaian diri sesuai dengan tingkat perkembangannya. Rajagrafindo Aisyah (2014). Layanan bimbingan dan konseling sebagai salah satu bagian penting dalam pelaksanaan pendidikan, mempunyai tugas dan tanggung jawab dalam membina perkembangan peserta didik untuk mampu membantu diri sendiri dalam memilih dan mengambil keputusan secara bertanggung jawab sehingga menjadi manusia yang berkembang optimal, produktif dan berudaya. Prinsip bimbingan dan konseling adalah "Guidance For All", artinya individu memiliki hak yang sama dalam mendapatkan layanan bimbingan dan konseling, siapa pun individu itu, dari mana pun individu itu berasal, dan bagaimana pun kondisi individu itu, semua mempunyai hak layanan.

\section{Pengertian Etika Pergaulan}

Secara Etimologi, kata etika berasal dari bahasa Yunani yang berarti ethos. Dalam bentuk tunggal "ethos" berarti tempat tinggal yang biasa, pandang rumput, kandang kebiasaan, adat, akhlak, perasaan, dan cara berfikir. Dalam istilah filsafat, etika berarti ilmu tentang apa yang biasa dilakukan atau ilmu tentang adat kebiasaan. Sedangkan dalam kamus Indonesia, etika diartikan sebagai ilmu tentang apa yang baik dan apa yang buruk dan tentang hak dan kewajiban moral, kumpulan asas/nilai yang berkenaan dengan akhlak dan nilai mengenai benar dan salah yang dianut suatu golongan atau masyarakat.

Menurut Jenjit. (2013) sejarahnya, istilah etika itu mula-mula digunakan oleh Montaigne, seorang penyair Prancis dalam syair-syairnya yang terkenal pada tahun 1580, yang berarti penilaian etika sebagai suatu ilmu, yang pada perbuatan baik atau jahat, susila atau tidak susila. Menurut Novita, Yani (2015), bahwa etika adalah nilai-nilai dan norma-norma yang menjadi pegangan bagi seseorang atau suatu kelompok dalam mengatur tingkah laku. Sedangkan menurut Suhaemi etika 
adalah ilmu tentang kesusilaan yang mengatur bagaimana sepatutnya manusia hidup di dalam masyarakat yang melibatkan aturan atau prinsip yang menentukan tingkah laku yang benar yaitu baik dan buruk atau kewajiban dan tanggung jawab. Menurut Novita, Yani (2015), etika adalah sebuah ilmu dan bukan sebuah ajaran. Yang memberi kita norma tentang bagaimana kita harus hidup adalah moralitas. Sedangkan etika justru hanya melakukan refleksi kritis atas norma atau ajaran moral tersebut. Etika bermaksud untuk membantu manusia bertindak secara bebas dan dapat dipertanggung jawabkan, karena setiap tindakannya selalu dilahirkan dari keputusan pribadi yang bebas dengan selalu bersedia untuk mempertanggung jawabkan tindakannya. Menurut Jenjit (2013) etika ialah ilmu yang mempelajari segala soal kebaikan dan keburukan didalam hidup manusia semuanya, teristimewa yang mengenai gerak-gerik pikiran dan rasa yang dapat merupakan pertimbangan dan perasaan, sampai mengenai tujuan yang dapat merupakan perbuatan.

Pergaulan secara etimologi kata bergaul indentik dengan kata "gaul" mengulas tentang kata gaul pada peradaban kejayaan romawi ada suku yang bernama suku gaul yang pada waktu itu bangsa gaul menjadi budak kaum romawi, konon katanya mereka diberi nama bangsa gaul dikarenakan mereka memiliki sifat dan karakteristik yang berbeda dengan bangsa atau suku lainnya. Sedangkan pengertian pergaulan secara terminologi yaitu menjunjung tinggi kebersamaan, persekawanan, dan persaudaraan yang dimana mereka lebih cenderung memiliki sifat afatisme dan hedonisme yang artinya mereka akan melakukan apapun untuk mencapai tujuannya. Pergaulan adalah kontak langsung antara individu dengan individu lain, atau antara pendidik dengan anak didik. Pergaulan juga memungkinkan menimbulkan pengertian yang mendalam antara tugas pendidik, yang wajib mendidik dan tugas anak didik yang wajib belajar. Saling mengetahui karena pergaulan tersebut dapat memudahkan usaha bimbingan dan pertolongan agar dilaksanakan dengan sebaik-baiknya.

\section{Konsep Etika Pergaulan}

\section{Etika Pergaulan}

Novita, Yani (2015) Dalam Keluarga Orang tua mempunyai peranan pertama dan utama bagi anak-anaknya selama anak belum dewasa dan mampu bediri sendiri. Untuk membawa anak kepada kedewasaan, orang tua harus memberi teladan yang baik karena anak suka mengimitasi kepada orang yang lebih tua atau orang tuanya. Dengan teladan yang baik, anak tidak merasa di paksa. Secara tidak langsung setiap anak berguru kepada saudara-saudaranya sehingga anak menjadi tahu bahwa dia merasa wajib memberi sebagaimana dia merasa perlu pemberian, baik materi maupun nonmateri. Antar anak dalam keluarga belajar tukar-menukar pengalaman sehingga semakin banyaklah halhal yang diketahui tentang baik dan buruk, hak dan kewajiban, tentang saling menyayangi, dan sebagainya dengan adanya hubungan satu sama lain.

2. Etika Pergaulan Dalam Sekolah

Sebagai lembaga pendidikan formal, sekolah terdiri dari pendidik dan anak didik. Antara mereka sudah tentu terjadi adanya saling hubungan, baik antara guru dengan murid-muridnya maupun antara murid dengan murid. Guru 
sebagai pendidik, dengan wibawanya dalam pergaulan membawa murid sebagai anak didik ke arah kedewasaan. Memanfaatkan pergaulan sehari-hari dalam pendidikan merupakan cara yang paling baik dan efektif dalam pembentukan pribadi dan dengan cara ini pula maka hilanglah jurang pemisah antara guru dan anak didik.

3. Etika Pergaulan di Lingkungan Masyarakat

Dalam konteks pendidikan, lingkungan masyarakat merupakan lembaga pendidikan selain keluarga dan sekolah yang akan membentuk kebiasaan, pengetahuan, minat dan sikap, kesusilaan, kemasyarakatan, dan keagamaan anak. Di masyarakatlah anak melakukan pergaulan yang berlangsung secara informal baik dari para tokoh masyarakat, pejabat atau penguasa, para pemimpin agama, dan sebagainya. Dengan demikian, dalam pergaulan seharihari antara seseorang dengan tokoh agama dan tokoh masyarakat mengandung gejala-gejala pendidikan karena para tokoh tersebut dalam pergaulannya mengarah kepada pengaruh yang positif, menuju kepada tujuan yang mencakup nilai luhur. Pergaulan sehari-hari antara anak dengan anak lainnya dalam masyarakat juga ada yang setaraf dan ada lebih dewasa di bidang tertentu. Teguran anak yang lebih dewasa, terhadap anak yang nakal, yang jorok, yang melakukan perbuatan-perbuatan berbahaya, dan sebagainya.

Berdasarkan konsep etika di atas dapat disimpulkan bahwa etika pergaulan terdapat 3 macam, yaitu yang pertama etika dalam berkeluarga, didalam berkeluarga seorang ayah yang dapat menjadi panutan kepada seorang anak.Ayah yang dapat memberikan yang baik dalam bertingkah laku yang baik. Yang kedua etika di dalam sekolah, etika didalam sekolah dapat dijadikan panutan yaitu seorang guru, guru harus mampu member contoh yang baik terhadap siswasiswinya. Dan yang ketiga etika di lingkungan masyarakat, etika ini membuat anak bergaul kepada siapa apakah anak tersebut bergaul di lingkungan yang bagus, jika memang dilingkungan yang bagus maka etika anak tersebut bagus juga, apa bila sebaliknya maka anak tersebut salah dalam bergaul.

\section{Teknik Sosiodrama}

Sosiodrama adalah metode pembelajran bermain peran untuk memecahkan masalah yang berkaitan dengan fenomena sosial, permasalahan yang menyangkut hubungan antara manusia seperti masalah kenakalan remaja, narkoba, gambaran keluarga yang otoriter, dan lain sebagiannya. Sosiodrama digunakan untuk memberikan pemahaman dan penghayatan akan masalah-masalah sosial serta pengembangan kemampuan siswa untuk memecahkannya.

Menurut Alhafizh. (2010) berpendapat bahwa teknik sosiodrama adalah merupakan salah satu teknik dalam bimbingan kelompok yaitu role playing atau teknik bermain peran dengan cara mendramatisasikan bentuk tingkah laku dalam hubungan sosial. Sosiodrama merupakan dramatisasi dari persoalan-persoalan yang dapat timbul dalam pergaulan dengan orang lain, tingkat konflik- konflik yang dialami dalam pergaulan sosial. Dalam sosiodrama digunakan role playing, yakni beberapa orang mengisi peranan tertentu dan memainkan suatu adegan tentang pergaulan sosial yang mengandung persoalan yang harus diselesaikan. Para pembawa peran membawakan adegan itu sesuai dengan peran yang telah 
ditentukan bagi masing-masing, adegan itu dibawakan dan dimainkan dihadapan sejumlah penonton yang menyaksikan adegan itu dan melibatkan diri dengan mendiskusikan jalan cerita setelah sandiwara selesai dimainkan. Menurut Kamus Besar Bahasa Indonesia, bahwa Sosiodrama adalah drama yang bertujuan memberikan informasi kepada masyarakat tentang masalah sosial dan politik. Adam Blatner dalam Baroroh, menyebutkan Role playing, a derivative of a sociodrama, is a method for exploring the issues involved in complex social situations. Sosiodrama pada dasarnya mendramatisasikan tingkah laku dalam hubungannya dengan masalah sosial sosiodrama dilaksanakan dalam sebuah proses pembelajaran.

Menurut Alhafizh. (2010), dengan mendramatisasikan tingkah laku dalam hubungannya dengan masalah sosial ini tujuannya agar siswa dapat menghayati dan menghargai perasaan orang lain, dapat belajar bagaimana membagi tanggung jawab, dapat belajar bagaimana mengambil keputusan dalam situasi kelompok secara spontan dan merangsang kelas untuk berpikir dan memecahkan masalah. Dalam situasi peranan yang di mainkan harus bisa berpendapat, memberikan argumentasi dan mempertahankan pendapatnya, tetapi bila perlu harus bisa mencari jalan keluar atau kompromi bila terjadi banyak perbedaan pendapat.

\section{METODE PENELITIAN \\ Jenis Penelitian}

Jenis penelitian yang akan dilaksanakan adalah penelitian dengan cara atau metode sendiri. Sebuah penelitian tindakan dalam menyelesaikan masalah yang dihadapi siswa dengan menerapkan teori bimbingan yang relevan serta kesulitan yang ditemukan. Langkah-langkah penelitian terdiri dari perencanaan, tindakan, pengamatan, dan refleksi. Kegiatan penelitian tindakan secara keseluruhan menerapkan siklus kegiatan, tergantung dari sejauhmana pencapaian indicator keberhasilan.

\section{Tempat, Waktu dan Subjek Penelitian}

Penelitian ini dilaksanakan di SMK Lembang. Penelitian ini dilaksanakan pada semester ganjil tahun ajaran 2019 / 2020 yaitu pada bulan Agustus sampai Oktober 2019. Adapun subjek penelitian yaitu siswa kelas XII yang diambil secara acak berjumlah 24 s orang.

\section{Metode dan Desain Intervensi Tindakan}

Metode penelitian yang digunakan adalah pemecahan dengan cara sendiri yaitu melalui teknik sosiodrama. Penelitian ini dilakukan secara kolaboratif dengan guru bidang Bimbingan Konseling di sekolah. Penelitian ini dilasanakan pada sejumlah siswa kelas XII yang diambil secara acak danmenggunakan dua siklus. Masing-masing siklus meliputi tahap perencanaan, pelaksanaan, pengamatan, dan refleksi. Model penelitian tindakan kelas yang akan digunakan adalah sebagai berikut: 


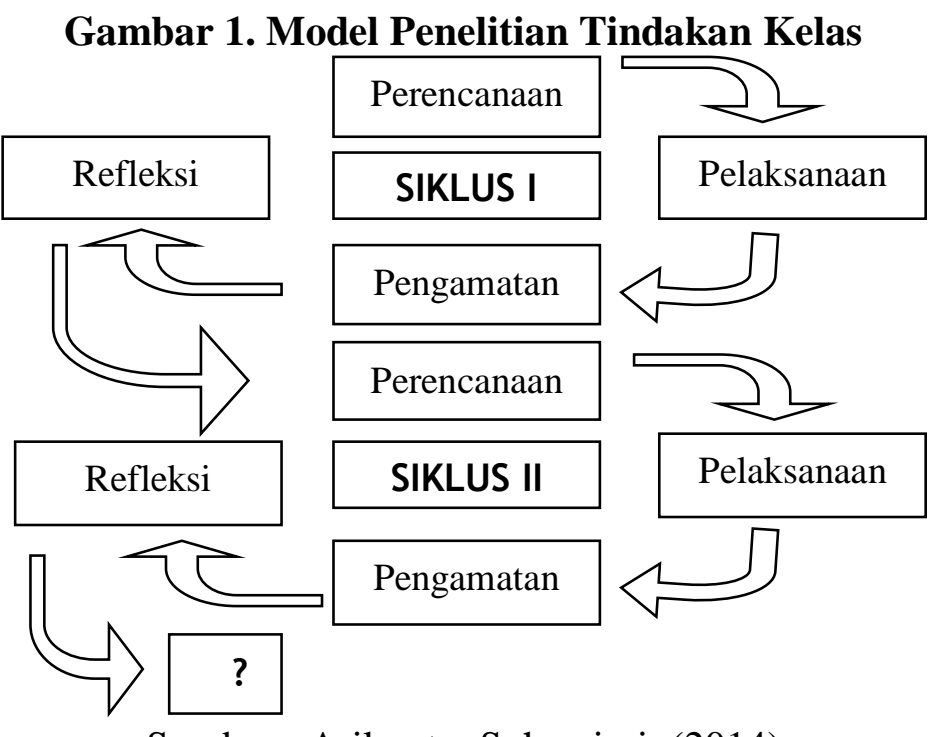

Sumber : Arikunto, Suharsimi. (2014)

\section{Teknik Pengumpulan Data}

Pada penelitian ini peneliti mengambil dua jenis data yaitu data kuantitatif dan data kualitatif.

Data kuantitatif berupa :

1. Data hasil tes (postes) setiap siklus.Siapkan rubrik soal.

2. Data kualitatif berupa:

3. Data hasil observasi setiap siklus.

4. Catatan lapangan.

5. Dokumentasi berupa foto.

\section{Tindak Lanjut Perencanaan Tindakan}

Setelah peneliti melakukan tindakan pada siklus I, maka ditindaklanjuti dengan melakukan tahapan pada siklus II, adapun tahapan dalam siklus II adalah sebagai berikut :

1. Perencanaan Tindakan

Identifikasi terhadap permasalahan layanan bimbingan konseling yang dijumpai pada siklus I serta penentuan alternatif pemecahan terhadap permasalahan tersebut. Kemudian dilakukan pengembangan skenario tindakan.

2. Pelaksanaan Tindakan

Pelaksanaan tindakan sesuai dengan skenario yang telah disusun.

3. Pengamatan Tindakan

Melakukan pengamatan terhadap tindakan dan mengumpulkan data-data penelitian dengan menggunakan instrumen yang telah disusun.

4. Refleksi Tindakan

Menganalisis, mengevaluasi dan melakukan refleksi data hasil penelitian. Kegiatan ini bertujuan untuk mengetahui apakah dari tindakan yang telah dilakukan menghasilkan suatu perubahan ke arah yang lebih baik dari siklus I. Jika hasil yang diperoleh sudah mencapai target yang diharapkan, maka penelitian ini dicukupkan pada siklus II ini. 


\section{HASIL PENELITIAN DAN PEMBAHASAN \\ Hasil Penelitian \\ Siklus I}

1. Rencana Tindakan Siklus I

Rencana pelaksanaa siklus I adalah bulan Agustus 2019 dengan mengadakan dua kali pertemuan.Sebelum melaksanakan penelitian layanan bimbingan konseling pada siklus I, guru BK sebagai peneliti akan mempersiapkan hal-hal yang digunakan dalam pelaksanaan penelitian. Guru BK menyampaikan maksud dan tujuannya kepada teman sejawatnya bahwa akan diadakan penelitian tentang Etika Pergaulan. Penelitian akan dilaksanakan di kelas tersebut karena ada masalah yang terjadi dengan siswa dan harus diatasi dengan mencari jalan keluar untuk diselesaikan. Siswa kelas XII diambil secara acak. Teman sejawatnya memberikan masukan yang positif tentang halhal yang harus disiapkan. Setelah mendapat dukungan dari rekannya maka guru sebagai peneliti mempersiapkan semuanya yang berpedoman pada langkahlangkah layanan bimbingan konseling yang akan dilaksanakan dan siap eksen. Rencana pelaksanaan siklus I ini di butuhkan waktu 1 x 45 menit dalam satu kali pertemuan.

2. Pelaksanaan Tindakan Siklus I

Pelaksanaan tindakan siklus I dimulai pada minggu kedua bulan Agustus 2019. Pada pertemuan pertama ini guru langsung mengutarakan maksud dan tujuan kepada siswa kelas XII bahwa akan diadakan penelitian tentang Etika Pergaulan. Pada siklus I ini guru belum menggunakan teknik sosiodrama tetapi hanya menjelaskan dan dibantu oleh observer untuk mengamati tingkah laku siswa selama pelaksanaan siklus I dan akan dinilai tehadap masing-masing siswa dengan tingkah laku pergaulan selama berada di kelas maupun di luar kelas. Untuk itu guru menghimbau kepada siswa agar berperilaku yang sopan baik terhadap teman, guru maupun orang di luar lingkungan sekolah. Setelah guru menyampaikan beberapa hal tersebut kepada siswa maka pada pertemuan pertama ini sudah mulai interaksi atau kegiatan terutama pada observer yang bertugas mengamati siswa dan dibantu oleh peneliti sendiri. Kegiatan ini sebelumnya sudah disampaikan terlebih dahulu oleh peneliti sesuai dengan langkah- langkah bimbingan konseling. Sesuai dengan langkah-langkah tersebut maka kegiatan diawali dengan pendahuluan, kegiatan inti dan penutup. Setelah kegiatan pelaksanaan berjalan dengan baik maka peneliti akan mengadakan penilaian dengan teknik penilaian tes tertulis.

Pelaksanaan siklus I pada pertemuan pertama cukup serius walaupun baru mulai dari awal karena dari hasil pengamatan aktifitas siswa, terlihat siswa mulai mengerti jika kegiatan yang dilakukan ada penilaian yang dilakukan oleh observer dan guru. Ada beberapa siswa yang melanggar dan dipanggil oleh guru sebagai konsoler untuk dibimbing. Selama seminggu kegiatan pertama belum ada tanda-tanda peningkatan sehingga peneliti akan melakukan pengamatan ulang pada pertemuan kedua. Pada pertemuan ke dua siklus I yang dilaksanakan pada minggu ke tiga bulan Agustus, guru sebagai konsoler memberikan arahan ulang kepada siswa kelas XII dan pada $\mathrm{p}$ ertemuan ke dua ini akan diadakan pengamatan lagi tentang etika pergaulan. Berdasarkan hasil 
pengamatan dan pengumpulan data yang diperoleh dari guru dan observer ternyata masih saja terjadi pelanggaran yang dilakukan oleh siswa. Jumlah siswa kelasXII yang diambil secara acak sebanyak 24 orang dan yang belum melaksanakan etika pergaulan dengan benar sekitar 12 orang dengan perincian laki-laki 5 orang dan perempuan 7 orang. Mereka ini setiap hari yang melakukan pelanggaran seperti masuk kelas terlambat, tidak rapi dalam berseragam, tidak memberi salam kepada teman, berbicara kasar, tidak mendengar teguran dari guru bahkan mengeluarkan bahasa yang tidak sopan. Semua tingkah laku ini dinilai oleh guru dan observer setiap hari. Siswa yang mengalami peningkatan dalam perilaku etika dalam bergaul dengan baik adalah 12 orang dengan nilai di atas KKM 70. Pada pertemuan kedua ini hasil yang dinilai adalah nilai perilaku siswa kelas XII selama melakukan pelanggaran. Prosentase ketuntasan nilai pada siklus I adalah 50\%.

3. Pengamatan Tindakan

Pada pelaksanaan tindakan siklus, pengamatan ditujukan pada aktifitas siswa yang diamati langsung oleh guru sebagai observer pertama dan teman sejawat sebagai observer kedua dan hasil nilai yang diperoleh pada siklus I. Untuk lebih jelasnya dapat dilihat deskripsi hasil pengamatan aktivitas dan nilai siswa siklus I pada tabel di bawah ini:

Tabel 1. Deskripsi Hasil Pengamatan Aktivitas Siswa kelas XII pada Siklus I

\begin{tabular}{|l|l|c|c|}
\hline \multirow{2}{*}{ No } & \multicolumn{1}{|c|}{ Aspek yang Dinilai } & \multicolumn{2}{|c|}{ Siklus I } \\
\cline { 3 - 4 } & & $\mathbf{1}$ & Pertemuan ke / Skor \\
\cline { 3 - 4 } & & 2 & 2 \\
\hline 1 & Antusias siswa mengikuti pelajaran & 2 & 3 \\
\hline 2 & Keseriusan siswa mengikuti pelajaran & 2 & 2 \\
\hline 3 & $\begin{array}{l}\text { Partisipasi dan aktifitas mengikuti } \\
\text { pelajaran }\end{array}$ & 2 & 2 \\
\hline 4 & Etika siswa dalam pergaulan di sekolah & 2 & 2 \\
\hline 5 & Keberanian siswa dalam berpendapat & 2 & 3 \\
\hline 6 & Kerjasama dengan siswa lain & 2 & 3 \\
\hline 7 & Prestasi yang dicapai siswa & 14 & 17 \\
\hline & Jumlah & $\mathrm{D}$ & $\mathrm{C}$ \\
\hline & Predikat & $2019)$ & \\
\hline
\end{tabular}

Sumber : Hasil Penelitian, diolah (2019)

Keterangan : 1 = tidak baik $2=$ cukup 3 = baik, dan $4=$ amat baik

Predikat Penilaian :

Amat Baik = Skor pencapaian 29-32

Baik = Skor pencapaian $24-28$

Cukup $\quad=$ Skor pencapaian $20-23$

Kurang $\quad=$ Skor pencapaian $<19$

Dari tabel diatas menjelaskan bahwa pada pelaksanaan siklus I hasil pengamatan aktifitas siswa kedua mendapat predikat $\mathrm{C}$ dengan total nilai 17 . Hal ini menunjukan aktivitas siswa pada siklus I belum meningkat dengan baik, masih ada pelanggaran yang dilakukan siswa dan harus diperbaiki pada pelaksanaan siklus ke dua. 


\section{Refleksi Tindakan}

Dari hasil pelaksanaan siklus I yaitu tahap perencanaan sampai dengan tahap pengamatan tindakan hasil yang dicapai cukup baik dimana pada pelaksanaan siklus I guru hanya menjelaskan teori dan mengambil penilaian berdasarkan hasil pengamatan yang dibantu oleh observer sehingga ada 12 siswa yang tuntas dan ada 12 siswa yang tidak tuntas. Kelemahan yang terjadi pada siklus I adalah guru mengajar hanya menjelaskan teori dan nilaiyang diperoleh darihasil pengamatan dan masih ada siswa yang melanggarnya sehingga harus diperbaiki metode atau cara pemecahan masalah yang lebih baik lagi pada pelaksanaan siklus II. Keuntungan yang diperoleh pada saat pelaksanaan siklus I adalah semua siswa selama pelaksanaan siklus I hadir dan mengikuti layanan bimbingan konseling. Dengan demikian pada pelaksanaan siklus II guru sebagai konselor dan juga sebagai peneliti akan menerapkan teknik sosiodrama atau bermain peran yang akan diperankan langsung oleh siswa sendiri dengan masalah-masalah yang dihadapi nanti.

\section{Siklus II}

\section{Perecanaan Siklus II}

Perencanaan siklus II akan dilakukan setelah melihat kelemahan yang terjadi pada pelaksanaan siklus I dan akan diperbaiki dengan membuat perencanaan yang lebih baik lagi. Peneliti menyusun rencana penelitian dengan meminta bantuan observer untuk melihat hal-hal apa saja yang harus didisiapkan sesuai dengan langkah-langkah layanan bimbingan konseling. Rencana pelaksanaan siklus II akan dilaksanakan pada minggu pertama dan minggu kedua bulan September 2019. Setelah persiapan direncanakan dengan baik maka pelaksanaan siklus II siap dilakukan.

2. Pelaksanaan Tindakan Siklus II

Pelaksanaan siklus II akan dilaksanakaan setelah tahap perencanaan disiapkan dengan baik. Pelaksanaan siklus II diawali dengan pertemuan pertama pada minggu pertama bulan September 2019. Waktu yang disiapkan adalah 45 menit dengan langkah- langkah kegiatan layanan kegiatan pendahuluan, kegiatan inti dan kegiatan penutup. Semunya sudah dibuat dalam metode atau cara pemecahan masalah. Pada pertemuan pertama ini guru atau peneliti akan menggunakan teknik sosiodrama dimana guru akan menyuruh siswa memerankan sesuai dengan masalah yang mereka hadapi. Guru membagi siswa dalam beberapa kelompok sesuai dengan masalah yang mereka lakukan. Setelah itu guru memberikan arahan kepada siswa tentang bagaimana memerankan suatu peran dengan masalah yang dihadapinya tentang Etika Pergaulan. Pengamatan ini hanya berlaku di kelas dan di luar kelas tidak sampai di luar lingkungan sekolah. Guru dan observer hanya mengamati tingkah laku siswa ketika jam sekolah. Siswa yang akan diamati adalah siswa kelas XII. Dari hasil pengamatan berlangsung siswa serius memerankannya tetapi ada siswa yang melakukannya dengan terpaksa karena malu dan takut. Guru berusaha membimbing siswa dan selalu memberi nasehat agar tidak melakukan hal- hal yang melanggar etika pergaulan. Pelaksanaan siklus II ini pada pertemuan pertama cukup seru karena ada perubahan tingkah laku siswa yang sudah mulai 
berubah dengan memerankan drama. Pertemuan pertama berakhir dengan baik ada beberapa siswa yang meningkat dan dilanjutkan lagi pada pertemuan kedua. Pertemuan kedua dilaksanakan pada minggu kedua bulan September. Pada pertemuan ini guru sebagai konselor bertugas memberikan bimbingan kembali tentang semua hal yang sudah dilakukan pada pertemuan pertama sampai ketiga. Masalah yang dihadapi siswa telah diperankan dengan teknik sosiodrama dan hasilnya ada perubahan dimana siswa mulai melakukan hal yang baik dan sudah mengerti tentang etika pergaulan. Dengan demikian dapat meningkatkan perilaku yang baik. Pertemuan ketiga ini guru memberikan beberapa soal kepada siswa tentang etika pergaulan dan langsung diperiksa bersama-sama. Hasil nilai yang diperoleh sangat baik karena semua siswa mencapai nilai di atas KKM 70. Guru dan siswa sangat puas dengan hasil yang dicapai. Dengan demikian guru sebagai peneliti menyampaikan kepada observer bahwa penelitian ini dihentikan dan tidak melanjutkan ke siklus III.

3. Pengamatan Tindakan

Seperti pada siklus I, pengamatan pada siklus II dilakukan oleh guru sendiri dan teman sejawat sebagai observer. Pada siklus II ini pengamatan dilakukan dari pertemuan pertama sampai pertemuan kedua. Pengamatan siklus II ini adalah lanjutan dari siklus I dengan point-point penilaian yang sudah disiapkan observer. Pengamatan ditujukan kepada aktivitas siswa kelas XII dalam tingkah lakunya baik di kelas maupun di luar kelas. Pada siklus II ini ada perubahan yang signifikan karena guru menerapkan teknik sosiodrama dalam layanan bimbingan konseling dimana siswa yang bermasalah akan melakonkan peran dengan masalah yang dibuatnya. Aktifitas siswa pada siklus II ini banyak mengalami perubahan. Mereka lebih berhati- hati dalam beretika karena takut melanggar lagi. Siswa tertihat antusias memerankan perannya dan hasil yang dicapai banyak siswa yang sudah mulai sadar dan berubah tidak melakukan pelanggaran dengan masalah yang sama. Hasil pengamatan dan hasil nilai siswa dapat di jelaskan pada tabel dibawah ini :

Tabel 2. Deskripsi Hasil pengamatan Aktivitas Siswa kelas XII pada Siklus II

\begin{tabular}{|l|l|c|c|}
\hline \multirow{2}{*}{ No } & \multicolumn{1}{|c|}{ Aspek yang Dinilai } & \multicolumn{2}{|c|}{ Siklus I } \\
\cline { 3 - 4 } & & $\mathbf{1}$ & Pertemuan ke / Skor \\
\cline { 3 - 4 } & & 3 & 4 \\
\hline 1 & Antusias siswa mengikuti pelajaran & 3 & 3 \\
\hline 2 & Keseriusan siswa mengikuti pelajaran & 3 & 3 \\
\hline 3 & $\begin{array}{l}\text { Partisipasi dan aktifitas mengikuti } \\
\text { pelajaran }\end{array}$ & 3 & 3 \\
\hline 4 & Etika siswa dalam pergaulan di sekolah & 2 & 3 \\
\hline 5 & Keberanian siswa dalam berpendapat & 3 & 4 \\
\hline 6 & Kerjasama dengan siswa lain & 3 & 4 \\
\hline 7 & Prestasi yang dicapai siswa & 20 & 24 \\
\hline & Jumlah & $\mathrm{C}$ & $\mathrm{B}$ \\
\hline & Predikat & $2019)$ & \\
\hline
\end{tabular}

Sumber : Hasil Penelitian, diolah (2019) 
Keterangan : $1=$ tidak baik $2=$ cukup $3=$ baik, dan $4=$ amat baik Predikat Penilaian :

Amat Baik $=$ Skor pencapaian $29-32$

Baik $\quad=$ Skor pencapaian $24-28$

Cukup $\quad=$ Skor pencapaian $20-23$

Kurang $=$ Skor pencapaian $<19$

Hasil pengamatan aktifitas siswa pada siklus I meningkat dengan baik dari hasil penilaian obsever pada pertemuan pertama mendapat skor 20 dengan predikat $C$ dan pada pertemuan kedua meningkat mencapai skor 24 dengan predikat B. Jadi ada peningkatan yang baik dari siklus I mendapat predikat $\mathrm{C}$ naik menjadi predikat

4. Refleksi Tindakan

Hasil pelaksanaan siklus II baik pertemuan pertama dan kedua mengalami perubahan yang baik dimana keuntungan yang diperoleh karena layanan bimbingan konseling ini menggunakan teknik sosiodrama sehingga siswa lebih mengerti dan paham tentang masalah yang dihadapi adalah tidak benar dan harus diperbaiki sehingga siswa lebih mengingatnya dan tidakakan mengulangi lagi. Hasil aktivitas siswa pada siklus II ini mengalami peningkatan yang baik juga dimana siswa aktif dan antusias mengikuti pelajaran. Hasil pengamatan Observer memberikan penilaian yang baik dimana pada siklus I mendapatkan predikat $\mathrm{C}$ dan pada siklus II meningkat menjadi predikat B. Nilai yang di peroleh diatas rata-rata KKM dan dari 24 siswa kelas XII dinyatakan tuntas. Kelemahan yang terjadi pada siklus II adalah siswa yang melanggar etika pergaulan merasa takut dan tidak mau bertanggungjawab dalam mengatasi masalah yang dibuatnya. Masalah ini bisa diatasi konsoler dengan memberikan bimbingan khusus sampai siswa bisa mengerti dan tidak mengulangi lagi. Dengan demikian peneliti dan observer mengambil suatu keputusan untuk menyimpulkan bahwa pelaksanaan siklus II dinyatakan tuntas dan tidak melakukan penelitian ke siklus berikutnya.

\section{Pembahasan}

Pada pembahasan ini akan dijelaskan tentang pelaksanaan siklus I dan siklus II dari aktifitas siswa dan hasil nilai siswa kelas XII yang akan dijabarkan pada tabel di bawah ini:

Tabel 3. Rekapitulasi Hasil Nilai Siswa Kelas XIII pada Siklus I dan Siklus II

\begin{tabular}{|c|c|c|c|}
\hline No & Uraian & Siklus I & Siklus II \\
\hline 1 & Aktifitas siswa & 17 & 24 \\
\hline 2 & Prosentase ketuntasan & $50 \%$ & $100 \%$ \\
\hline 3 & Predikat & C & B \\
\hline 4 & Siswa yang Tuntas & 12 & 12 \\
\hline
\end{tabular}

Sumber : Hasil Penelitian, diolah (2019)

Pada tabel diatas menerangkan bahwa aktivitas siswa pada siklus I mendapat point 17 dengan predikat cukup (C) dan jumlah siswa yang tuntas sebanyak 12 orang dengan prosentase ketuntasan mencapai $50 \%$ sedangkan pada pelaksanaan siklus II mengalami peningkatan yang baik dimana aktivitas siswa mendapat point 24 dengan predikat baik (B) dan jumlah siswa yang tuntas 24 
orang dengan prosentase ketuntasan mencapai $100 \%$. Hal ini menunjukan bahwa bimbingan layanan konseling dengan menggunakan teknik sosiodrama berhasil dan tuntas sehingga penelitian ini dihentikan sampai dengan siklus II.

\section{KESIMPULAN DAN SARAN \\ Kesimpulan}

Berdasarkan latar belakang sampai dengan pembahasan dalam penelitian tindakan kelas ini maka disimpulkan bahwa layanan bimbingan konseling tentang etika pergaulan dengan teknik sosiodrama dapat meningkatkan perilaku baik pada siswa kelas XII dengan ketuntasan belajar dari siklus I 50\% meningkat menjadi $100 \%$ pada siklus II sehingga penelitian dihentikan pada siklus II.

\section{Saran}

1. Bagi Siswa

Dengan mengikuti layanan bimbingan konseling di sekolah tentang etika pergaulan yang diberikan oleh guru sebagai konsoler diharapkan dapat meningkatkan perilaku siswa kearah yang lebih baik sehingga dapat meningkatkan prestasi belajarnya baik di sekolah, keluarga dan masyarakat

2. Bagi Guru

Meskipun penelitian telah mencapai siklus II dan tidak melakukan penelitian ke siklus berikutnya, namun diharapkan peneliti yang lain bisa melanjutkan penelitian ini secara signifikan dan dapat menerapkan model pembelajaran lain dalam layanan bimbingan konseling sehingga dapat meningkatkan wawasan berpikir dan kreatif bagi guru mata pelajaran BK.

3. Bagi Sekolah

Diharapkan pihak sekolah mendukung guru dalam pemberian bimtek tentang penulisan PTK sehingga dapat meningkatkan mutu pendidikan sekolah yang berkualitas.

\section{DAFTAR PUSTAKA}

Abdul Jalaludin. 2010. Pelaksanaan Kegiatan Bimbingan dan Konseling di SMK Al Hidayah 1 Cilandak Jakarta Selatan. UIN Syarif Hidayatulloh : Jakarta. ABKIN. 2010. Kode Etik Profesi Bimbingan dan Konseling Indonesia. Semarang. Afifudin. 2012. Bimbingan dan Konseling. Bandung:CV.PUSTAKA SETIA.

Ahman. 2013. Konsep Dasar Bimbingan Konseling Perkembangan. Jakarta :

Alhafizh. 2010. Metode Sosiodrama dan Bermain Peran. Tersedia dalam http://alhafizh84.wordpress.com/2010/01/16/metode-sosiodramadanbermain-peranan-role-playing-method/ (10 maret 2012).

Anas Salahudin. 2012. Bimbingan \& Konseling. Bandung: CV.PUSTAKA SETIA. Aqib

Arikunto, Suharsimi. 2014. Prosedur Penelitian Suatu Pendekatan Praktik. Jakarta: Rineka Cipta.

Jenjit. 2013. Dunia Pergaulan dan Etika dalam Pergaulan. (OnLine). Tersedia dalam http://jenjitpuriningtias.wordpress.com/2013/09/10/duniapergaulandan-etika-dalam-pergaulan/

Lestari, Novia Dian. 2013. Pengaruh Layanan Informasi dengan Metode Diskusi 
Terhadap Peningkatan Etika Pergaulan Siswa. Semarang: Fakultas Ilmu Pendidikan IKIP PGRI Semarang.

Megayani. 2013. Etika dalam Pergaulan. (OnLine). Tersedia dalam http://megayaniimei.wordpress.com/2013/09/09/makalah-etikadalampergaulan/

Novita, Yani. 2015. Peran Orang Tua dalam Membentuk Etika Pergaulan Peserta Didik di Kelas XI SMA N 14 Padang. Skripsi. Padang: Program Studi Bimbingan dan Konseling PGRI Sumatera Barat.

Rajagrafindo Aisyah. 2014. Strategi Layanan Bimbingan dan Konseling Bagi Siswa Tunanetra MTS Yaketunis Yogyakarta (tesis) Program Pascasarjana UIN Sunan Kalijaga

Sutirna. 2014. Bimbingan dan Konseling Pendidikan Formal,Nonformal dan Informal. Yogyakarta: CV. Andi Offset.

Zainal. 2012. Ikhtisar Bimbingan dan Konseling di Sekolah. Bandung: YRAMA WIDYA 